\title{
A multiparametric assay to compare the cytotoxicity of different storage media for avulsed teeth
}

\author{
Emmanuel João Nogueira Leal Silva', Carolina Bluzarca Rollemberg², \\ Tauby de Souza Coutinho-Filho ${ }^{3}$, Renato Liess Krebs ${ }^{3}$, Alexandre Augusto Zaia ${ }^{1}$ \\ ${ }^{1}$ Department of Restorative Dentistry, Area of Endodontic, Piracicaba Dental School, University of Campinas, Piracicaba, SP, Brazil \\ Dentist, Rio de Janeiro, RJ, Brazil \\ ${ }^{3}$ Department of Endodontic, State University of Rio de Janeiro (UERJ), Rio de Janeiro, RJ, Brazil
}

Received for publication: January 21, 2013 Accepted: May 08, 2013

Correspondence to: Emmanuel João Nogueira Leal Silva Rua Herotides de Oliveira 61/902 CEP: $24230-230$ - Niterói, RJ, Brasil Phone: +552183575757 E-mail: nogueiraemmanuel@ hotmail.com

\begin{abstract}
Aim: To evaluate the cytotoxicity of several storage media (coconut water, whole milk, isotonic solution, Hank's Balanced Salt Solution and tap water) using a multiparametric cytotoxicity analysis employing $3 \top 3$ cells. Methods: Plates containing confluent $3 T 3$ fibroblasts were exposed to the various media for $24 \mathrm{~h}$, at $37^{\circ} \mathrm{C}$ with $5 \% \mathrm{CO}_{2}$, and cell viability was evaluated by a multiparametric assay assessing sequentially, on the same cells, mitochondrial activity (XTT), membrane integrity (neutral red test), and total cell density (crystal violet dye exclusion test). Results from each test were compared by one-way analysis of variance (ANOVA). Results: Statistical analysis showed that whole milk and HBSS were the most effective media in maintaining cell viability at all tested times $(p<0.05)$. Isotonic and tap water showed the highest cytotoxicity effects. Conclusions: This study shows that whole milk and HBSS are more efficient in maintaining the viability of 3 T3 fibroblasts as demonstrated by three different cell viability tests.
\end{abstract}

Keywords: tooth avulsion, fibroblasts, cell viability.

\section{Introduction}

Tooth avulsion is one of the main issues in dental traumatology because it is a severe dental injury. Due to the complexity of this injury, the neurovascular supply is severely compromised in most cases, causing loss of pulp vitality ${ }^{1}$. The main etiological factors are trauma after fighting and sports, as well as falls and bumps against hard objects and/or the floor ${ }^{2}$. The incidence of tooth avulsion accounts approximately $1-16 \%$ of all traumatic injuries in the permanent dentition and $7-21 \%$ in the primary dentition ${ }^{3-4}$.

When dental avulsion occurs, immediate replantation at the trauma site is the ideal procedure for maintaining the viability of periodontal ligament (PDL) cells. However, immediate replantation is rarely achieved ${ }^{5}$, principally because of lack of dental knowledge from parents/tutors at the moment of the accident. The viability of PDL cells relies on three critical factors: the duration of extra-alveolar time, preservation of the root and storage media of the tooth, all of which determine the prognosis for dental replantation ${ }^{2-5}$. Inflammatory resorption and replacement 
resorption along with dental alveolar ankylosis are the most signiûcant and common complications after replantation of avulsed teeth ${ }^{2-3}$. Thus, to avoid further damage do the PDL cells, it is important to select an appropriate storage medium to keep their viability.

Different transport media for avulsed teeth have been investigated to evaluate their capacity to preserve the vitality of PDL components and dental pulp tissue until replantation ${ }^{1,6-9}$. The ideal storage medium should preserve cell vitality, adherence and clonogenic capacity ${ }^{10}$ and must be easily accessible and available at the site of the accident ${ }^{11}$. Examples are: saliva, milk, Hank's Balanced Salt Solution (HBSS), SaveA-Tooth system (Phoenix-Lazerus, Shartlesville, PA, USA), and ViaSpan (DuPont Phamaceuticals, Wilmington, DE, USA). Other storage media include egg white, powdered milk, Gatorade (The Gatorade Co., Chicago, IL, USA), and propolis, all of which were recently studied and tested ${ }^{1,5-11}$.

The simultaneous evaluation of different cell viability parameters, in a multiparametric assay, may identify more accurately any possible cytotoxic effects of storage media with immortalized cells intimately related to the in-vivo tissue. Therefore, the aim of this study was to compare the cytocompatibility of different storage media. Cytocompatibility was assessed by a multiparametric assay employing 3T3 fibroblasts.

\section{Material and methods}

Cell viability in the following storage media was evaluated: long-shelf-life coconut water (Taeq, Fortaleza, CE, Brazil), isotonic beverage (Gatorade®, São Paulo, SP, Brazil), Hank's Balanced Salt Solution (Gibco BRL, Grand Island, NY, USA), long-shelf-life whole milk (Parmalat, São Paulo, SP, Brazil) and tap water. Cells cultured in Dulbecco's Modified Eagle Medium (DMEM) served as positive control. The $\mathrm{pH}$ of all solutions was measured with a digital $\mathrm{pH}$ meter (Hanna Instruments, Ann Arbor, MI, USA) at room temperature. The osmolality was tested with an automatic cryoscopic osmometer (Osmomat 030, Gonotec, Berlin, Germany).

Fibroblast cells (lineage 3T3) were obtained from the American Type Culture Collection and were cultured in DMEM supplemented with 10\% fetal bovine serum (FBS) (Gibco, Grand Island, NY, USA), $100 \mu \mathrm{g} / \mathrm{ml}$ streptomycin, and $100 \mathrm{mg} / \mathrm{mL}$ penicillin at $37^{\circ} \mathrm{C}$ in a humidified incubator at room atmosphere containing $5 \% \mathrm{CO}_{2}$. Confluent cells were detached with $0.25 \%$ trypsin and $0.05 \%$ ethylenediaminetetraacetic acid (Gibco, Grand Island, NY, USA) for $5 \mathrm{~min}$, and aliquots were sub-cultured. For the experimental set, 5 $\mathrm{x} 10^{3}$ cells were cultured in 96-well culture plates and allowed to achieve $80 \%$ confluence. After $24 \mathrm{~h}$, the medium was removed from each well and replaced by $200 \mu \mathrm{L}$ of one of the tested storage media for $24 \mathrm{~h}$.

Cytotoxicity was evaluated with a commercial kit (Cytotox; Xenometrix, Germany) that measures three different cell viability parameters sequentially in the same cell culture: XTT, neutral red test (NR), and crystal violet dye exclusion test (CVDE). The XTT test is based on the ability of mitochondrial enzymes from metabolically active cells to reduce 2,3-bis(2-methoxy-4-nitro-5-sulphophenyl)-2Htetrazolium-5-carboxanilide (XTT) molecules to a soluble salt of formazan, detectable by its absorbance at $480 \mathrm{~nm}$, as measured by a spectrophotometer (Urit 660; Urit, China). The same cells submitted to the XTT test were washed and assayed with the neutral red uptake test (NR), which determines the levels of viable cells by their membrane integrity. The vital dye NR is incorporated by endocytosis and accumulates preferentially on the lysosomes of intact viable cells membrane. After $3 \mathrm{~h}$ of exposure to the dye, cells were fixed and the NR was extracted and measured by the optical density (OD) of the supernatant at $540 \mathrm{~nm}$, which directly relates to the proportion of viable cells. After the NR test, fixed cells were washed and evaluated for the total density of adhered cells, as estimated by the crystal violet dye exclusion test (CVDE). CVDE is a simple assay that evaluates cell density by staining DNA; after elimination of excess dye, the absorbance at $540 \mathrm{~nm}$ is proportional to the amount of cells in the well.

Data from the assays are presented as means \pm standard deviation (SD). The results were subjected to the Kolmogorov-Smirnov test to evaluate the normal distribution, and data were analyzed using one-way analysis of variance (ANOVA). Statistical differences among the groups were analyzed using the Tukey test at a significance level of 5\%. Data were analyzed using the statistical software SPSS ${ }^{\circledR}$ (SPSS, Inc., Chicago, IL, USA).

\section{Results}

Figure 1 shows cell viability as evaluated by three different assays, after exposure to 24-h of the different storage media, expressed as a percentage of the control (cells exposed to DMEM). As seen in panels A, B, and C, tap water and isotonic have higher cytotoxic effects, as measured by all three employed methods. Coconut water had better results than tap water and isotonic $(\mathrm{p}<0.05)$. No significant difference was found between whole milk and HBSS $(\mathrm{p}<$ 0.05 ) that have the lowest cytotoxic effects. The results of $\mathrm{pH}$ and osmolality are expressed in Table 1.

\section{Discussion}

Dental trauma is described in the literature as a common problem among children and adolescents throughout the world ${ }^{5,12-14}$. Among the different types of dental trauma,

Table $1-\mathrm{pH}$ and osmolality of different storage media

\begin{tabular}{lll}
\hline Material & Osmolality $(\mathrm{mOsmol} / \mathbf{k g})$ & $\mathrm{pH}$ \\
Coconut water & 375 & 4.6 \\
Tap water & 2 & 8.2 \\
Long shelf-life milk & 283 & 6.8 \\
Gatorate & 404 & 3.0 \\
DMEN & 311 & 8.0 \\
HBSS & 280 & 7.6 \\
\hline
\end{tabular}




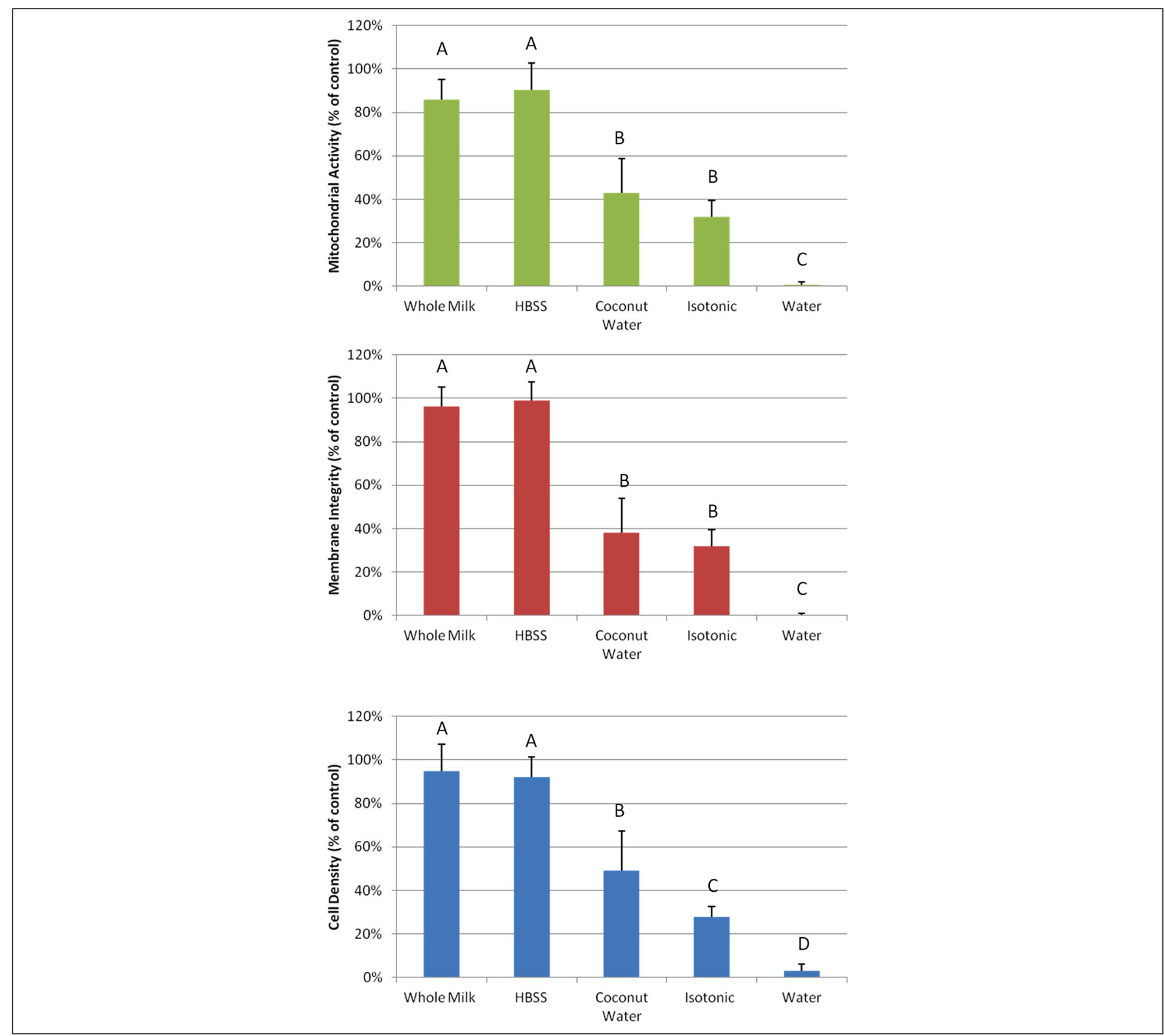

Fig. 1. Cytotoxic effects of storage media on $3 T 3$ cells by XTT (A), NR (B), and crystal violet dye exclusion test (C), expressed as percentage of control (cells exposed to culture medium). Bars indicate mean $\pm \mathrm{SD} .\left(^{*}\right)$ mean statistically significant differences between tested groups $(\mathrm{p}<0.05)$.

avulsion leads to the greatest functional and esthetic impairment due to its worse prognosis ${ }^{2-5}$. The ideal outcome after replantation of an avulsed tooth is regeneration of the periodontal ligament, which is possible when the vitality of PDL cells is maintained. The cells that remain on the root after exarticulation are deprived of their blood supply and immediately begin to deplete their stored cell metabolites. Hammer ${ }^{15}$, demonstrated that the length of survival of a replanted tooth is directly related to the amount of viable periodontal ligament and the major factors that may influence the viability of the periodontal ligament fibroblasts are the extra-alveolar time and the storage medium ${ }^{2-5,8,16}$. Therefore, many studies aimed to preserve avulsed tooth in a proper medium $^{1,6-11,16}$. The storage medium should be able of preserving cell vitality and adherence capacity and also be readily available at the moment of avulsion to allow rapid access to it $^{17-18}$.

In previous studies, various techniques were used to quantify the number of viable PDL cells including the trypan blue assay ${ }^{1,7-8,10,16}$, XTT assay ${ }^{6}$ and MTT assay ${ }^{9}$. In the present study, storage media cytotoxicity was tested employing a methodological strategy that differs from most previous works on these materials by employing a multiparametric assay with three different cell viability tests. In this manner, three different parameters were evaluated on the same sample: (1) mitochondrial metabolism and respiratory toxicity, (2) liposomal integrity and membrane permeability and (3) presence of DNA and cell proliferation. This method increases the chance of detection of cytotoxic effects, allows correlation of different parameters, and sometimes provides hints about the mechanisms of toxicity ${ }^{19-20}$. A 3 T3 fibroblast cell line was used in this study for its easy preparation and handling. 
Studies with established cell lines are used because of the reproducibility of the results and besides they multiply rapidly with an unlimited life $\operatorname{span}^{21-22}$. Fibroblasts are major constituents of connective tissue and the predominant cell type of periodontal ligament.

Many materials have been evaluated for use as storage media. HBSS is a widely used standard solution recommended by the International Association of Dental Traumatology as a storage medium for avulsed teeth ${ }^{5}$. In this study, HBSS, tap water, milk, coconut water and isotonic solution were tested. HBSS and long shelf-life milk showed the best results when compared with the other tested solutions $(p<0.05)$. HBSS is a standard saline solution, which is widely used in biomedical research to support the growth of many cell types ${ }^{23-24}$. A commercially available tooth preserving system utilizing HBSS as a storage medium, Save-A-Tooth, has become available for storage of avulsed teeth until replantation. An added advantage of this system is an inner suspension net and a removable basket which permits general washing and removal of the tooth, without crushing the periodontal ligament by the dentist ${ }^{25}$. In the present study, HBSS was used simulating the Save-A-Tooth system. Although HBSS showed excellent results in the multiparametric assay, it is not easily available in pharmacies or drug stores at the site of an accident. Therefore, milk is known as the appropriate storage medium for avulsed tooth for its physiological properties, including $\mathrm{pH}$ and osmolality compatible to those of the cells from the PDL; the easy availability, the advantage of not requiring refrigeration and for being bacteria-free $e^{6,8,10-11,18}$. The favorable results of milk probably occur due to the presence of nutritional substances, such as amino acids, carbohydrates and vitamins ${ }^{6,10-11,17-18,25-26}$. Coconut water showed better results when compared with Gatorade ${ }^{\circledR}$ and tap water $(p<0.05)$. Coconut water is biologically pure and sterile, with a rich presence of amino acids, proteins, vitamins and minerals ${ }^{8,25}$. The acidic $\mathrm{pH}$ (4.6) could be deleterious to cell metabolism, explaining the intermediate results. Among the studied storage media, tap water and Gatorade ${ }^{\circledR}$ showed the worst results. Although Gatorade ${ }^{\circledR}$ could be a potential storage media because it is commonly found at sports events, it did not turn out to be an adequate storage media for avulsed teeth due its acid $\mathrm{pH}$ (3.0).

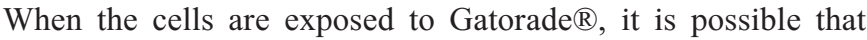
their membrane gets damaged because of this low $\mathrm{pH}$, which turns impossible cell growth ${ }^{18}$. The hypertonic osmolality (404.0) also can make the cells lose water. Different explanation could be given to tap water, as it causes rapid cellular lyses of PDL due to its hypotonic osmolality (2.0).

According to the results of this study, it could be concluded that milk and HBSS have the best results using the multiparametric assay, corroborating their use in cases of tooth avulsion.

\section{References}

1. Martin MP, Pileggi R. A quantitative analysis of Propolis: a promising new storage media following avulsion. Dent Traumatol. 2004; 20: 85-9.

2. Trope M. Avulsion of permanent teeth: theory to practice. Dent Traumatol. 2011; 27: 281-94.
3. Soares AJ, Gomes BP, Zaia AA, Ferraz CC, de Souza-Filho FJ. Relationship between clinical-radiographic evaluation and outcome of teeth replantation. Dent Traumatol. 2008; 24: 183-8.

4. Andreasen JO, Borum MK, Jacobsen HL, Andreasen FM. Replantation of 400 avulsed permanent incisors 1. Diagnosis of healing complications. Endod Dent Traumatol. 1995; 11: 51-8.

5. Flores MT, Andersson L, Andreasen JO, Bakland LK, Malmgren B, Barnett $F$ et al. International Association of Dental Traumatology. Guidelines for the management of traumatic dental injuries. II. Avulsion of permanent teeth. Dent Traumatol. 2007; 23: 130-6.

6. Gjertsen AW, Stothz KA, Neiva KG, Pileggi R. Effect of propolis on proliferation and apoptosis of periodontal ligament fibroblasts. Oral Surg Oral Med Oral Pathol Oral Radiol Endod. 2011; 112: 843-8.

7. Moazami F, Mirhadi H, Geramizadeh B, Sahebi S. Comparison of soymilk, powdered milk, Hank's balanced salt solution and tap water on periodontal ligament cell survival. Dent Traumatol. 2012; 28: 132-5.

8. Gopikrishna V, Baweja PS, Venkateshbabu N, Thomas T, Kandaswamy D. Comparison of coconut water, propolis, HBSS, and milk on PDL cell survival. J Endod. 2008; 34: 587-9.

9. Hwang JY, Choi SC, Park JH, Kang SW. The use of green tea extract as a storage medium for the avulsed tooth. J Endod. 2011; 37: 962-7.

10. Ashkenazi $M$, Marouni $M$, Sarnat $H$. In vitro viability, mitogenicity and clonogenic capacity of periodontal ligament cells after storage in four media at room temperature. Endod Dent Traumatol. 2000;16: 63-70.

11. Huang SC, Remeikis NA, Daniel JC. Effects of long-term exposure of human periodontal ligament cells to milk and other solutions. J Endod. 1996; 22: 30-3.

12. Bastone EB, Freer TJ, McNamara JR. Epidemiology of dental trauma: a review of the literature. Aust Dent J. $2000 ; 45:$ 2-9.

13. Piovesan C, Guedes RS, Casagrande L, Ardenghi TM. Socioeconomic and clinical factors associated with traumatic dental injuries in Brazilian preschool children. Braz Oral Res. 2012; 26: 464-70.

14. Correa MB, Schuch HS, Collares K, Torriani DD, Hallal PC, Demarco FF. Survey on the occurrence of dental trauma and preventive strategies among Brazilian professional soccer players. J Appl Oral Sci. 2010; 18: $572-6$.

15. Hammer H. Replantation and implantation of teeth. Int Dent J. 1955; 5 : 439-57.

16. Khademi AA, Saei S, Mohajeri MR, et al. A new storage medium for an avulsed tooth. J Contemp Dent Pract. 2008; 9: 25-32.

17. Santos CL, Sonoda CK, Poi WR, Panzarini SR, Sundefeld ML, Negri MR. Delayed replantation of rat teeth after use of reconstituted powdered milk as a storage medium. Dent Traumatol. 2009; 25: 51-7.

18. Chamorro MM, Regan JD, Opperman LA, Kramer PR. Effect of storage media on human periodontal ligament cell apoptosis. Dent Traumatol. 2008; 24: 11-6.

19. Scelza MZ, Linhares AB, da Silva LE, Granjeiro JM, Alves GG. A multiparametric assay to compare the cytotoxicity of endodontic sealers with primary human osteoblasts. Int Endod J. 2012; 45: 12-18.

20. De-Deus G, Canabarro A, Alves G, Linhares A, Senne MI, Granjeiro JM. Optimal citocompatibility of a bioceramic nanoparticulate cement in primary human mesenchymal cells. J Endod. 2009; 35: 1387-90.

21. Loushine BA, Bryan TE, Looney SW, Gillen BM, Loushine RJ, Weller RN et al. Setting properties and cytotoxicity evaluation of a premixed bioceramic root canal sealer. J Endod. 2011; 37: 673-7.

22. Bouillaguet S, Wataha JC, Tay FR, Brackett MG, Lockwood PE. Initial in vitro biological response to contemporary endodontic sealers. J Endod. 2006; 32: 989-92.

23. Casaroto AR, Hidalgo MM, Sell AM, Franco SL, Cuman RK, Moreschi $E$ et al. Study of the effectiveness of propolis extract as a storage medium for avulsed teeth. Dent Traumatol. 2010; 26: 323-31.

24. Krasner P, Person P. Preserving avulsed teeth for replantation. J Am Dent Assoc. 1992; 23: 80-8. 
25. Thomas T, Gopikrishna V, Kandaswamy D. Comparative evaluation of maintenance of cell viability of an experimental transport media "coconut water" with Hank's balanced salt solution and milk for transportation of an avulsed tooth: An in vitro cell culture study. J Conserv Dent. 2008; 11:22-9.

26. Marino TG, West LA, Liewehr FR, Mailhot JM, Buxton TB, Runner RR, et al. Determination of periodontal ligament cell viability in long shelf-life milk. J Endod. 2000; 26: 699-702. 